\title{
Spinduliavimo ịtaka vandens lašelių energinei būsenai ir garavimui
}

Gintautas Miliauskas,

\section{Kristina Norvaišienè}

Šilumos ir atomo energetikos katedra, Kauno technologijos universitetas, K. Donelaičio g. 20, LT-44239 Kaunas El.paštas: gimil@ktu.lt

\begin{abstract}
Sumodeliuotas vandens lašelių garavimas sudetinio jų šildymo atveju, kai išorinio spinduliavimo šaltinio temperatūra atitinka lašelių apsupties temperatūrą. Tyrimo rezultatai pateikti universalaus laiko, išreikšto Furje kriterijumi, masteliu. Spinduliavimo poveikis lašelių energinei būsenai ir garavimui ịvertintas palyginamuoju metodu pagal energijos srautų ir garavimo parametrų kitimą aprašančių kreivių nukrypimą nuo etaloninių. Pastarosiomis laikytos laidumu šildymų lašelių energijos srautų ir garavimo parametrų kitimo kreivės, Furjẻ kriterijumi išreikštame laike nepriklausančios nuo lašelių dispersiškumo. Išryškintas spinduliavimo poveikis garuojančių lašelių pernašos procesų sąveikoje. Spinduliavimo ịtaka ryškesnė stambesniesiems lašeliams ir stiprèja augant apsupties temperatūrai.
\end{abstract}

Raktažodžiai: vandens lašelių garavimas, sudètinis šildymas, pernašos procesų sąveika

\section{IVADAS}

Išpurkšti skysčiai plačiai pritaikomi terminėse technologijose [1]. Dvifazis vandens lašelių ir dujų srautas yra efektyvi priemonė paviršių apsaugai nuo aukštos temperatūros poveikio, lašelių šilumos ir masès mainų procesų intensyvumas lemia oro kondicionavimo, dujų aušinimo, ugnies fronto slopinimo, tirpalų garinimo, fakelo temperatūros reguliavimo ir kitų termoinžinerijai svarbių procesų efektyvumą. Nors skysčio išpurškimu besiremiančios terminès technologijos yra savitos, tačiau šilumos ir masès pernašos procesų jose modeliavimo prasme jas vienijanti grandis yra pusskaidrio skysčio lašeliai. Jų šilumos ir masès mainų tyrimai vadinami bendru „lašo uždavinio"vardu ir tęsiasi ilgiau nei šimtmetį [2], tačiau ir toliau išlieka aktualūs dèl poreikio tobulinti esamas bei kurti naujas skysčio išpurškimu grindžiamas technologijas. Ankstyvieji "lašo" tyrimai apžvelgti [2, 3], vèlesnieji aptarti [4]. Išryškinta lašelių šilumos ir masès mainų vyksmo sąlygų i̇vairove ir juos sąlygojančių parametrų gausa. Dèl „lašo uždavinio“ i̇vairiapusiškumo praktinio taikymo prasme ir pernašos procesų vyksmo sąlygu ìvairovès bei specifikos yra taikomi skirtingi eksperimentiniai ir teoriniai jo sprendimo metodai, kurie gana išsamiai ir sistemingai išanalizuoti [5]. Pastarųjų metų "lašo" tyrimuose ryškus siekis kuo išsamiau atsižvelgti ị sudètinès pernašos nestacionariụjų procesų sąveikos, vykstančios dèl nuo garuojančio lašelio sklindančio Stefano hidrodinaminio srauto ir pusskaidriame skystyje sugeriamo spinduliuotės srauto poveikio, įtaką jų intensyvumui $[1,6,7]$. Atsižvelgti ị Stefano hidrodinaminio srauto poveikị lašelio šilimui ir garavimui leidžia [8-10] darbų rekomendacijos, o spektrinès spinduliuotès ịtaką energinei lašelių būsenai ịvertinti galima pagal $[1,11,12]$ „lašo “ modelius. Teorinių tyrimų rezultatų patikimumui svarbi eksperimentinè kontrolè. Lašeliu garavimo spinduliuojančioje apsuptyje eksperimentiniai tyrimai yra sudètingi ir gana reti. Išskirtiniais galima laikyti V. Ivanovo ir E. Smirnovos atliktus vandens lašelių pusiausviro garavimo greičio eksperimentinius matavimus [13], kai lašeli šildo apsupties oras ir pastarąji gaubianti spinduliuojanti sienelè. Pro sienelejje įrengtus langus sistemos centre ant kapiliarinio vamzdelio galo kabantis lašelis buvo apšviečiamas ir iki 50 kartų padidinta jo projekcija stebima ekrane. Lašelio temperatūra išmatuota pro kapiliarą ivvesta termopora. Kapiliarine sistema ị garuojantị lašelị tiektas vanduo, kurio debitas išmatuotas specialiai tam sukonstruotu įrenginiu. Specialiu termostatu tiekiamo vandens temperatūra reguliuota pagal išmatuotą garuojančio lašelio temperatūrą. Oro parametrų pastovumo užtikrinimui ir laisvosios konvekcijos i̇takos sumažinimui taikytas lètas vandens garų išsiurbimas iš garavimo kameros. Keičiant vandens debitą stengtasi kompensuoti išgaruojantị skystị ir išlaikyti numatytą lašelio 
stambumą, kol buvo pasiekiamos lašelio pusiausviro garavimo sąlygos. Apie jas spręsta pagal nusistovèjusią garuojančio lašelio temperatūrą ir nekintantị tiekiamo vandens debitą. Pastarasis prilygintas lašelio pusiausviro garavimo greičiui. Ištirtas $0,9-2,9 \cdot 10^{-3} \mathrm{~m}$ skersmens stambių vandens lašelių garavimas apsupties temperatūrai kintant nuo 400 iki $800^{\circ} \mathrm{C}$. Eksperimento autorių vertinimu pusiausviro garavimo greičių matavimo rezultatų neapibrèžtis buvo ne didesnè kaip $5 \%$ [13].

Šildymo sąlygų ịtaką lašelių terminei būsenai ir faziniams virsmams galima ịvertinti palyginamuoju metodu, kai nuosekliai einama link sudètingesnių kraštinių šilumos ir masės mainų sąlygų. Tam būtinas gerai ištirtas lašelių šilumokaitos atvejis. Juo galima laikyti lašelių šildymą laidumu, kai spinduliavimo bei savaiminès ir priverstinès šilumos konvekcijos įtaka yra paneigiama. Laidumu šildomų vandens lašelių šilimo ir garavimo procesai yra kruopščiai ištirti ir pasižymi daugeliu palyginamajai analizei patogiu savybių, kurios išryškẻja šilumos ir masès mainų parametrų kitimą aprašančias kreives pateikus Furjẻ kriterijumi išreikštame laiko mastelyje [14]. Apsupties oro drègnumu ir temperatūra apibrěžtose sąlygose, laidumu šildomo lašelio terminès būsenos kitimą aprašančios jo paviršiaus ir masès vidutinès temperatūrų kitimo kreivès Furjè kriterijumi pateiktame laike nepriklauso nuo lašelio dispersiškumo ir gali praversti sudètingesnio šildymo poveikio ịvertinimui. Svarbu tai, jog laidumu šildomiems lašeliams būdingos kitimo kreivès egzistuoja ne tik terminès būsenos parametrams, bet ir bematès formos šilumos mainų bei fazinių virsmų parametrams. Jas sudarant reikia tinkamai parinkti normuojančius parametrus [15].

Pritaikius „hipotetinio“ lašelio modelį, kuriame lašeliui šylant ir garuojant jo matmuo nekinta, šiame darbe yra teoriškai atkurtos [13] darbe pateiktų vandens lašelių pusiausviro garavimo eksperimentinio tyrimo sąlygos. Skaitiškai ištirtas vandens lašelių garavimas skirtingais sudètinio šildymo atvejais. Pateiktas spinduliavimo ịtakos vandens lašelių garavimui palyginamasis ivvertinimas, modeliavimo rezultatai palyginti su eksperimentinio tyrimo rezultatais.

\section{TYRIMO METODAS}

Taikomas $[6,10,11]$ darbuose išvystytas kombinuotas analitinio ir skaitinio „lašo“ uždavinio tyrimo metodas, kompleksiškai apjungiantis nestacionariuosius sudètinius šilumos ir masės mainus lašelyje ir jo apsuptyje. Šylančio ir garuojančio pusskaidrio skysčio lašelio paviršiaus temperatūra skaičiuojama pagal iteracinę skaitinę schemą, kuri pritaikyta lašelio paviršiuje sąveikaujančių energijos srautu balansą aprašančiai lygčiai išspręsti. Pastarajai reikia prie lašelio paviršiaus pritekančiu ir nutekančių energijos srautų atitikimo ir formaliai ji užrašoma pagal lašelyje ir jo apsuptyje veikiančius suminius šilumos srautus bei fazinių virsmų šilumos srautą:

$$
\vec{q}_{\Sigma}^{+}(\tau)+\vec{q}_{\Sigma}^{-}(\tau)+\vec{q}^{+}(\tau) \equiv 0
$$

Siekiant konkretizuoti (1) lygtị, reikia atsižvelgti i garuojančio lašelio konvekcinio šildymo intensyvumą, spinduliuotès sugèrimą pusskaidriame skystyje, nestacionariojo temperatūros lauko gradiento ypatumus lašelyje bei lašelio paviršiuje vykstančių fazinių virsmų spartą. Nestacionarusis temperatūros laukas spinduliavimu ir laidumu šildomame lašelyje aprašomas integraline lygtimi

$$
T(r, t)=T_{R}+\frac{2}{r} \sum_{n=1}^{\infty} \sin \frac{n \pi r}{R} \int_{0}^{t} f_{n} \cdot \exp \left[-a\left(\frac{n \pi}{R}\right)^{2}(t-\tau)\right] d \tau ;
$$

čia $f_{n}$ funkcija atsižvelgiama ị spinduliuotės srauto sugèrimo ypatumus lašelyje ir jo paviršiaus temperatūros kitimo spartą [11]. Konvekcinès šilumos srautas lašelyje aprašomas pagal modifikuotą Furjè dèsni

$$
\left.q_{c}^{-}(\tau) \equiv k_{e f}^{-} \cdot \lambda \cdot \frac{\partial T(r, \tau)}{\partial r}\right|_{r=R^{-}},
$$

i skysčio cirkuliacijos galimą ịtaką šilumos plitimui lašelyje atsižvelgiant efektyvaus šilumos laidumo parametru [9]. Skysčio lašelyje šildymo intensyvumą atspindi suminis šilumos srautas $q_{\Sigma}^{-}=q_{c}^{-}+q_{r}^{-}$. Jo spinduliavimo sandą apskaičiuojant pagal [11] metodiką, atsižvelgiama ỉ pusskaidrio skysčio kompleksinio lūžio rodiklio kitimo spinduliavimo spektre ypatumus, šviesos spindulio lūžio ir atspindžio efektus abiejose lašelio paviršiaus pusèse bei sugèrimą lašelyje. Vandens optinès spektrinès charakteristikos gerai žinomos [16]. Konvekcinès šilumos srautas ị lašelị apskaičiuojamas pagal modifikuotą Niutono šilumos atidavimo dèsni

$$
q_{c}^{+}(\tau)=\frac{\lambda_{v g} \cdot \mathrm{Nu}}{2 R} \cdot\left[T_{g}-T_{R}\right] \cdot f\left(B_{T}\right) .
$$

(4) išraiškoje Spoldingo šilumos parametro funkcija atsižvelgiama i Ł Stefano hidrodinaminio srauto poveikị garuojančio lašelio konvekcinio šildymo intensyvumui pagal [10] metodiką. Laidumu šildomam lašeliui $\mathrm{Nu} \equiv 2$ ir $q_{c}^{+} \equiv q_{k}^{+}$. Lašelio paviršiuje vykstančių fazinių virsmų šilumos srautą lemia garo srautas lašelio paviršiuje ir skysčio prigimtis [17]:

$$
\begin{aligned}
& q_{f}^{+}(\tau) \equiv L \cdot m_{v}^{+}=L \cdot \frac{D_{v g} \cdot \mu_{v}}{T_{R} \cdot R_{\mu} \cdot R}\left[p_{v, R}-p_{v, \infty}+\right. \\
& \left.+\frac{\mu_{v}}{\mu_{g}}\left(p \cdot \ln \frac{p-p_{v, \infty}}{p-p_{v, R}}-p_{v, R}+p_{v, \infty}\right)\right] .
\end{aligned}
$$

Pradinėmis šilumos ir masės mainų sąlygomis numatomas lašelio stambumas ir išpurškiamo skysčio temperatūra. Parinkus spinduliavimo šaltinio ir dujų temperatūras bei numačius skysčio garo tūrinę dalị jose, apibrěžiami lašelio apsupties parametrai. Modeliuojant vienišo lašelio garavimą, apsupties parametrai laikomi nekintančiais. Prie (1)-(5) algebrinių ir integralinių lygčių sistemos prijungiama garuojančio lašelio masẻs kitimą aprašanti diferencialinè lygtis. „Hipotetiniam“ nekintančio tūrio lašeliui vietoj jos taikoma papildoma sąlyga:

$$
\frac{d R(\tau)}{d \tau} \equiv 0 .
$$


(1)-(6) lygčių sistemos skaitinio sprendimo schema sudaroma numatytoje lašelio šildymo tyrimo kontrolinejje trukmejje parinkus baigtinị skaičių $\tau_{i}$ tarpinių verčių, o bematę lašelio koordinatę $\eta_{j} \equiv r_{j} / R$ padalijus ị baigtinị skaičių $\Delta \eta_{j} \equiv \eta_{j+1}-\eta_{j}$ intervalų. Daromas $\Delta \tau_{i} \equiv \tau_{i+1}-\tau_{i}$ žingsnelis laike. Pirmojoje iteracijoje spinduliavimo srautas lašelyje apskaičiuojamas atsižvelgus i $\tau_{i}$ laiko momentu buvusị temperatūros lauką lašelyje, o vèlesnėse iteracijose atsižvelgiama ị ankstesneje iteracijoje apskaičiuotą temperatūros lauką. Lašelio paviršiaus temperatūra atrenkama greičiausio nusileidimo metodu minimizuojant konkretizuotą (1) funkcionalą, užtikrinant ne didesni kaip dešimtoji procento prie lašelio paviršiaus pritekančių ir nuo jo nutekančių šilumos srautų neatitikimą. Determinavus lašelio paviršiaus temperatūros $T_{R}(\tau)$ funkciją, apskaičiuojami ir kiti lašelio šilumos ir masès mainus aprašantys parametrai.

\section{TYRIMO REZULTATAI}

Sumodeliuotas laidumu ir spinduliavimu šildomo nejudančio vandens lašelio garavimas $T_{g}$ temperatūros sausame ore, kai lašelio pradinė $T_{0}$ temperatūra yra žemesnè už pusiausviram garavimui būdingą lašelio paviršiaus $T_{R, e}$ temperatūrą, jo paviršiuje veikiančiam hipotetiniam masès šaltiniui užtikrinant (6) sąlygą. Šildymo laidumu atveju numatoma nespinduliuojanti lašelio apsuptis ir paneigiama savaiminès šilumos konvekcija joje. Sudètinio šildymo atveju spinduliuoja orą gaubianti pilka sienelè, kurios juodumo laipsnis lygus 0,95, o temperatūra atitinka oro temperatūrą: $T_{s} \equiv T_{g}$. Spinduliavimo šaltinio ịtaka lašelių energinei būsenai ir garavimui ịvertinta ištyrus terminès būsenos ir garavimo spartos bei šilumos srautų lašelyje kitimą nestacionariųjų fazinių virsmų režime. Jo metu lašeliai pašyla nuo $T_{0}$ temperatūros iki pusiausviram garavimui būdingos $T_{e}$ temperatūros (1 pav.). Pusiausviru garavimu suvokiamas fazinių virsmų režimas, kai apsupties suteikta šiluma lašelị tik garina. Lašelio terminès būsenos kitimo ypatumus lemia jo šildymo būdas [10], todèl bendruoju atveju pusiausvirai garuojančio lašelio terminę būseną galima apibrèžti tik lašelio masès vidutine temperatūra: $T_{e} \equiv T_{m, e}$. Laidumu šildomas lašelis pusiausvirai garuoti gali pasiekęs terminę būseną su nulinio gradiento temperatūros lauku, užtikrinančią $q_{c, e}^{-}=0$ ir $q_{f, e}^{+} \equiv q_{k, e}^{+}$sąlygas ( 2 pav.). Laidumu šildomų realaus ir hipotetinio lašelių pusiausviro garavimo terminę būseną galima nusakyti ir lašelio paviršiaus temperatūra $T_{e, k} \equiv T_{m, e, k} \equiv T_{R, e, k}$, kuri pusiausviro garavimo režime išlieka pastovi. Laisvai parinktiems apsupties parametrams laidumu šildomo lašelio paviršiaus ir jo masès vidutinès temperatūros kitimą aprašančias $T_{R, k}(\mathrm{Fo})$ ir $T_{m, k}(\mathrm{Fo})$ kreives (1 pav., $b$ 1-3, 7-9 kreivès) galima laikyti būdingomis, kadangi jos atspindi terminès būsenos kitimą visų tos pačios pradinès temperatūros vandens lašelių, kuriems Knudseno sluoksnio poveiki galima paneigti. Temperatūras jose sunormavus lašelio pradinès ir pusiausviro garavimo temperatūrų atžvilgiu, $\bar{T} \equiv\left(T-T_{0} / T-T_{e, k}\right)$, sudaroma laidumu šildomų lašelių terminès būsenos kitimo universali $\bar{T}\left(\mathrm{Fo} / \mathrm{Fo}_{e, k}\right)$ kreivè
[14]. Pastarąją palyginamajame sudètingesnių už šildymą laidumu sąlygų itakos lašelių terminei būsenai ịvertinime galima laikyti etalonine. Išpurškiamo skysčio temperatūros, oro temperatūros ir drégnumu nusakytų apsupties konkrečių parametrų atveju spinduliavimo šaltinio ịtaką gerai atspindi ir nukrypimas nuo būdingụjų terminès būsenos kitimo kreivių (1 pav., b). Sudètinio šildymo atveju lašelių terminę būseną labai veikia pusskaidriame skystyje sugertas spinduliuotès srautas. Dèl jo įtakos vykstanti pernašos procesų sąveika sukelia vietines nestacionariojo temperatūros lauko lašelyje deformacijas, lemiančias netgi temperatūros lauko gradiento vektoriaus krypties vandens lašelyje pokyti. Tai sudaro prielaidą skystyje sugertą spinduliuotès srautą perduoti ị lašelio paviršių ir ịtraukti i skysčio garinimo procesą (3 pav.). Sudètinio šildymo atveju pusiausviram skysčio garavimo režimui prasidèti būtina sąlyga: $q_{c, e}^{-}=q_{r, e}^{-}$ir $q_{f, e}^{+}=q_{\Sigma, e}^{+} \equiv q_{c, e}^{+}+q_{c, e}^{-}$.

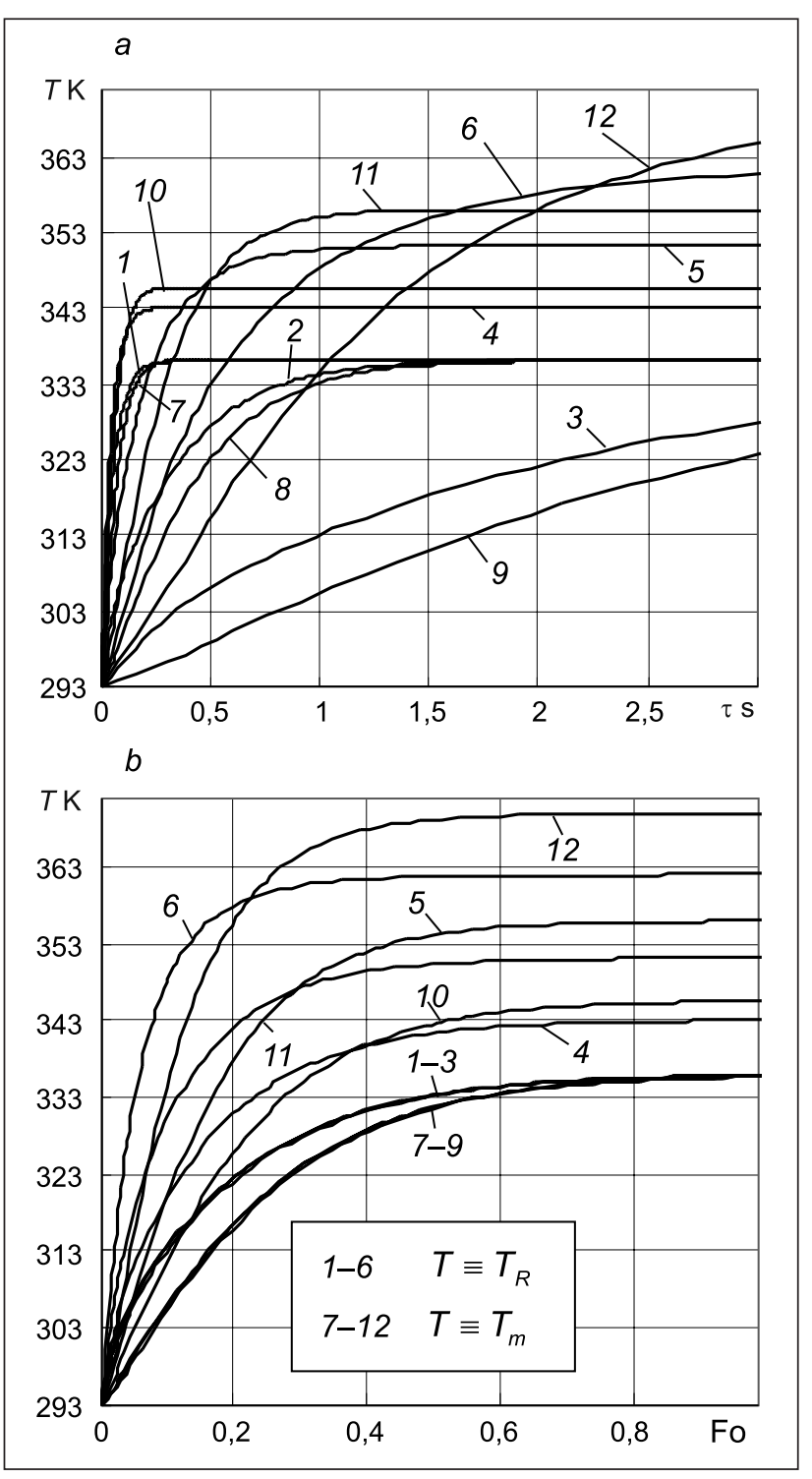

1 pav. Šylančio hipotetinio lašelio temperatūros kitimas nestacionariojo garavimo režime: (1-3,7-9) šildymas laidumu, $(4-6,10-12)$ sudètinis šildymas. $R_{0} \cdot 10^{6}$, m: $(1,4,7,10) 200,(2,5,8,11) 500,(3,6,9,12) 1200 ; T_{g}=1133 \mathrm{~K} ; T_{0}=293 \mathrm{~K}$ 


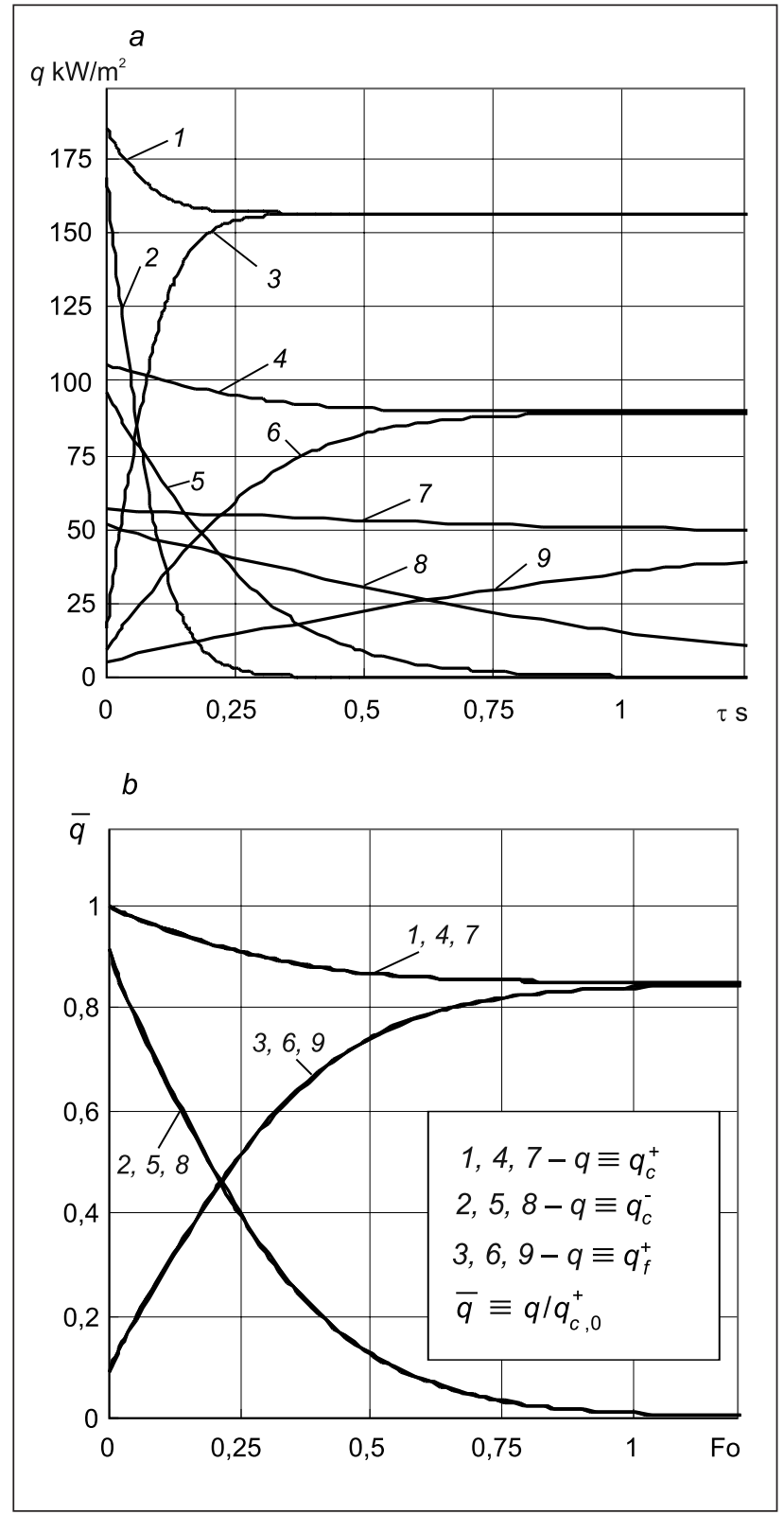

2 pav. Šilumos srautų kitimas nestacionariojo garavimo režime laidumu šildomo hipotetinio lašelio paviršiuje: (a) realiame laike, (b) Furje kriterijumi išreikštame laike. $R_{0} \cdot 10^{6}(\mathrm{~m}): 1-3-200,4-6-350,7-9-650 ; T_{0}=1133 \mathrm{~K} ; T_{0}=293 \mathrm{~K}$

Esmines nestacionariojo temperatūros lauko lašelyje transformacijas patvirtina lašelio paviršiaus ir masès vidutinès temperatūros kreivių susikirtimas nestacionariojo garavimo režime (1 pav.). Vèliau stebimas šių kreivių išsisluoksniavimas rodo sugerto spinduliavimo srauto sukeltą lašelio vidinių sluoksnių aukštesnị pašilimą. Neizotermiškumo kitimą lašelio garavimo metu atspindi lašelio paviršiaus ir centro temperatūrų skirtumas (4 pav.). Pradineje garavimo stadijoje jo augimą lemia spartus paviršinių lašelių sluoksnių šilimas veikiant išoriniam šilumos konvekcijos srautui. Pastarajam vis labiau įsitraukiant ị skysčio garinimą (2, 3 pav.), neizotermiškumas lašelyje pradeda slopti, kol palaipsniui tampa nuliniu (4 pav.). Laidumu šildomiems lašeliams tai rodo

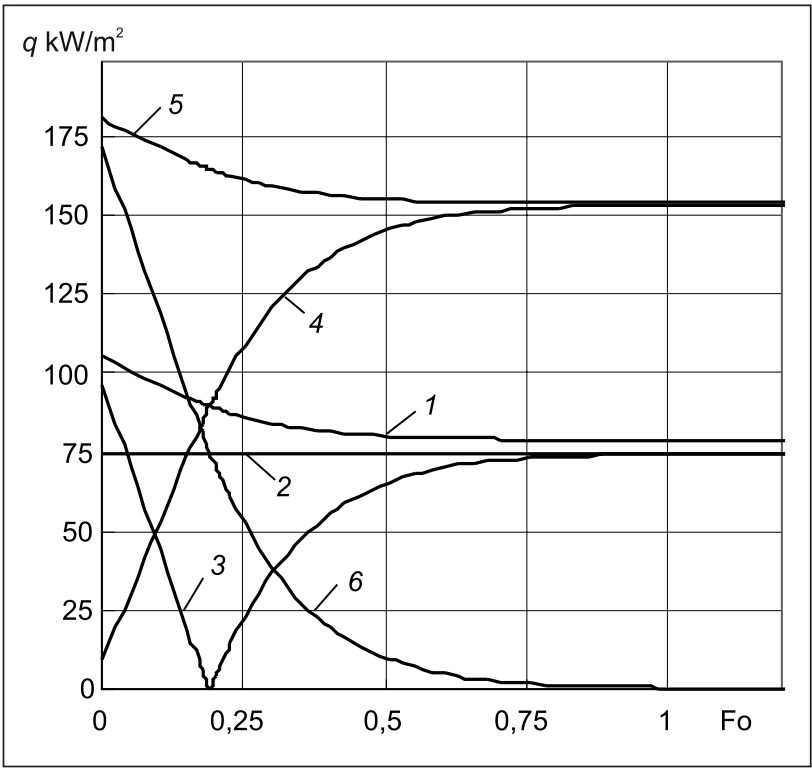

3 pav. Šilumos srautų kitimas nestacionariojo garavimo režime hipotetinio lašelio paviršiuje sudètinio šildymo atveju. $T_{g}=1133 \mathrm{~K} ; T_{0}=293 \mathrm{~K} ; R_{0}=350 \cdot 10^{-6} \mathrm{~m}$. Parametro $q$ prasmè: $1-q_{c^{\prime}}^{+} 2-q_{r^{\prime}} 3-q_{c^{\prime}}^{-} 4-q_{f^{\prime}}^{+} 5-q_{\Sigma^{\prime}}^{+} 6-q_{c}^{-}$

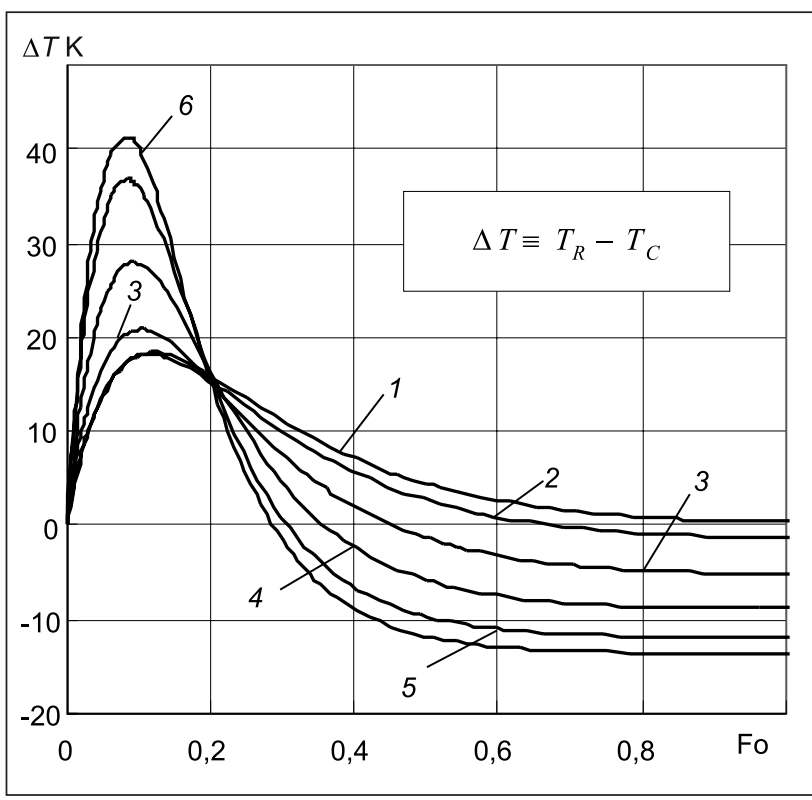

4 pav. Neizotermiškumo kitimas šylančiame hipotetiniame lašelyje ji šildant laidumu (1) ir sudètinio šildymo atveju (2-8). $R_{0} \cdot 10^{6}(\mathrm{~m}): 2-200,3-350$, $4-650 ; T_{g}=1133 \mathrm{~K} ; T_{0}=293 \mathrm{~K}$

nestacionariojo garavimo režimo pabaigą, o sudètinio šildymo atveju - perejjimą í baigiamąją jo stadiją, kurios metu dèl spinduliavimo poveikio pasiekiamas antrasis neizotermiškumo lašelyje pikas. Kadangi spinduliuotes srauto sugèrimas kiekvienam skirtingo stambumo lašeliui yra individualus, todèl neizotermiškumo kitimas sudètinio šildymo atveju lašeliuose yra irgi savitas. Smulkesniuosiuose lašeliuose jo kitimas artimesnis šildymo laidumu atvejui. Vandens hipotetinio lašelio pusiausviro garavimo režimas gali tęstis be galo 
ilgai neizotermiškumui jame nekintant. Pastarojo pokyčius gali sukelti tik apsupties parametrų pakitimas. Realaus gi lašelio neizotermiškumas pusiausviro garavimo eigoje slopsta dèl spinduliuotès srauto sugèrimo mažėjančiame lašelyje silpnèjimo [11].

Laidumu šildomiems skirtingo stambumo lašeliams stebimas šilumos srautų dinamikos ekvivalentiškumas Furjè kriterijumi išreikštoje trukmëje (3 pav.) sudaro prielaidas ir kitų šilumos bei masès mainų parametrų, tarp jų ir lašelių garavimo spartos (5 pav.), kitimą aprašančių būdingụjų kreivių egzistavimui. Šios kreivès patogios ịvertinti lašelių dispersiškumo įtaką pernašos procesų sąveikoje, kadangi sudetinio šildymo atveju stebimas šilumos ir masès mainų parametrų kitimo nukrypimas nuo būdingųjų kreivių aiškiai parodo pastarojo ittaką jiems išpurškiamo skysčio tempera-

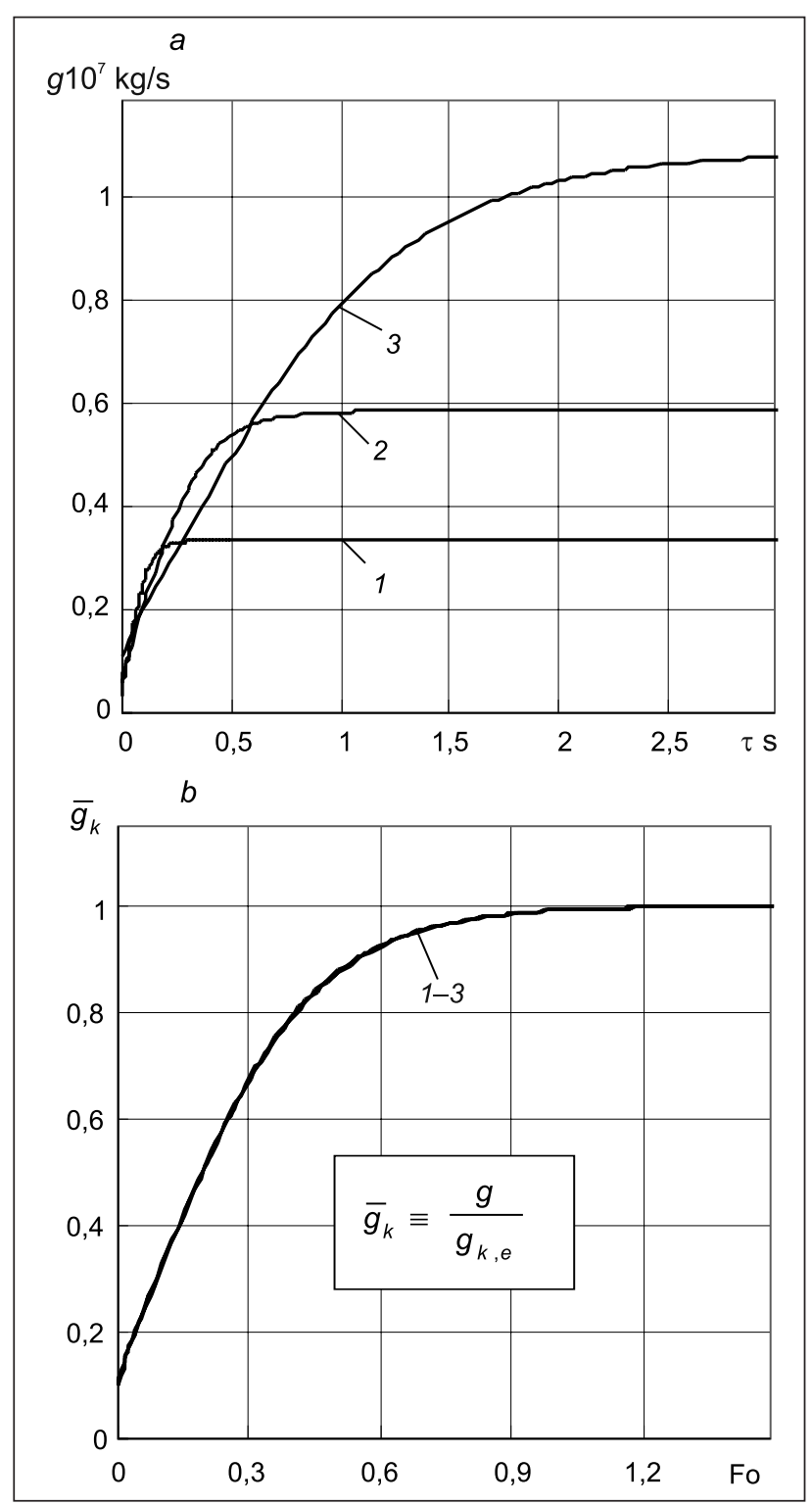

5 pav. Laidumu šildomo hipotetinio lašelio garavimo greičio kitimas nestacionariojo garavimo režime: $a$ - realiame laike, $b$ - Furje kriterijumi išreikštame laike. $R_{0} \cdot 10^{6}(\mathrm{~m}): 1-200,2-350,3-650 ; T_{q}=1133 \mathrm{~K} ; T_{0}=293 \mathrm{~K}$ tūra ir lašelių apsupties parametrais apibrèžtu atveju (6 pav.). Nestacionariųjų fazinių virsmų režime sparčiai augęs šylančio hipotetinio lašelio garavimo greitis palaipsniui nusistovi artèjant prie pusiausviro garavimo. Sudètinio šildymo atveju pusiausviras garavimas kur kas spartesnis už laidumu šildomo lašelio garavimą, o jo apskaičiuotasis greitis gerai dera su [13] darbe pateiktais eksperimentinio tyrimo rezultatais (7 pav.).

Lašelio šilumos ir masès mainų parametrų kitimo būdingųjų kreivių pobūdị labai veikia išpurškiamo skysčio temperatūra ir lašelio apsupties parametrai, o tai rodo fazinių virsmų šilumos srauto kitimo būdingųjų kreivių šeimos pavyzdys (8 pav., a). Todèl spinduliavimo ịtakos išryškinimas ir apibendrintas šios įtakos įvertinimas plačiame kraštinių sąlygų diapazone yra imlus darbui. Čia plačias perspektyvas atveria atskirų parametrų kitimo būdingų kreivių šeimos sutraukimas ił universaliąsias kreives. Pastarosioms sudaryti būtina numatyti būdingas kreives normuojančius tinkamus parametrus, užtikrinančius tiriamojo parametro kitimą universaliame 0-1 intervale, ir pritaikyti Furjè kriterijų santykiu išreikštą laiko kitimo universalų 0-1 intervalą. Laidumu šildomų lašelių nestacionariojo fazinių virsmų režimo universalią $0-1$ trukmę atspindi pusiausviro garavimo pradžią nurodančio Furjè kriterijaus atžvilgiu normuotas $\overline{\mathrm{F}} \mathrm{o}_{k} \equiv \mathrm{Fo} / \mathrm{Fo}_{e, k}$ laiko parametras, o lašelio šilumos ir masès mainų $P$ parametrai normuojami jų pradinių ir pusiausviro garavimo verčių atžvilgiu:

$$
\bar{P}_{i n, k} \equiv \frac{P_{i n, k}-P_{i n, 0}}{P_{i n, e, k}-P_{i n, 0}} .
$$

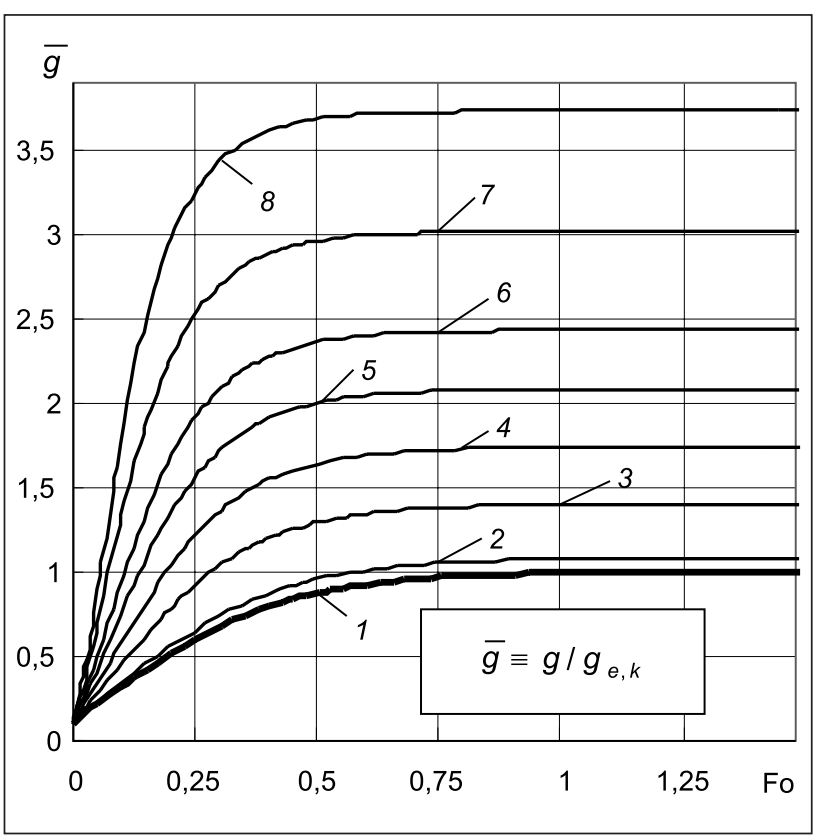

6 pav. Lašelio dispersiškumo ịtaka garavimo greičiui sudetinio šildymo atveju: $R_{0} \cdot 10^{6}(\mathrm{~m}): 2$ - 50, 3 - 200, 4 - 350, 5 - 500, 6 - 650, 7 - 900, 8 - 1200; $T_{g}=1133 \mathrm{~K} ; T_{0}=293 \mathrm{~K}$. Laidumu šildomo lašelio pusiausviro garavimo greitis $g_{e, k} \cdot 10^{7}(\mathrm{~kg} / \mathrm{s}): 2-0,0836 ; 3-0,3343 ; 4-0,5853 ; 5-0,8364 ; 6-1,087$; $7-1,507 ; 8-2,011,1-$ būdinga garavimo greičio kitimo kreivè 


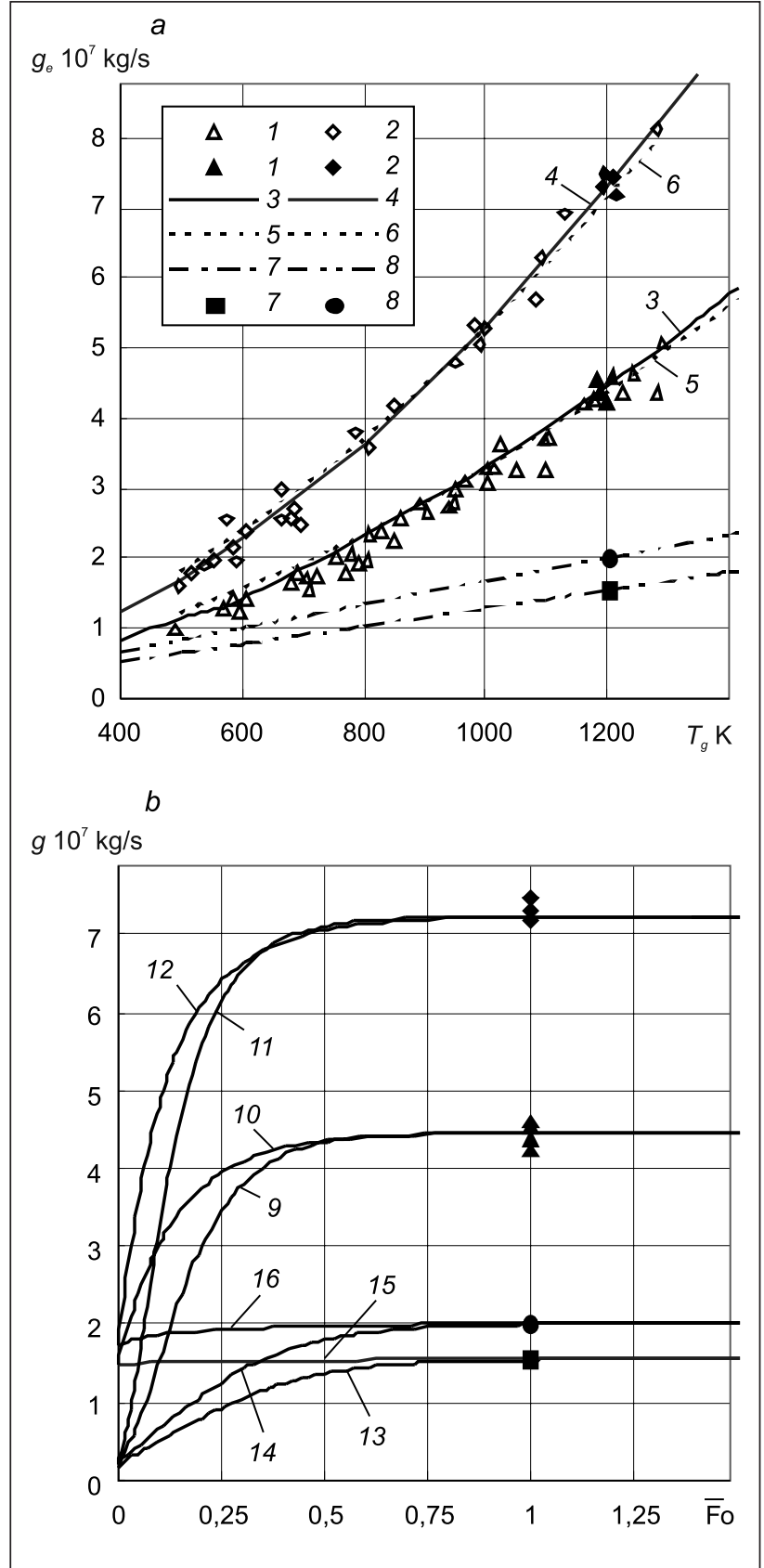

7 pav. Šildymo būdo įtaka vandens lašelių pusiausviro garavimo greičiui $(a)$ ir hipotetinio lašelio garavimo greičiui nestacionariujų fazinių virsmų režime $(b)$. (1-6, 9-12) - sudètinis šildymas; (7, 8, 13-16) - šildymas laidumu; 1, 2 - eksperimentas [13]; skaitinis tyrimas: $3,4,7,8-[15] ; 5,6-[1] ; 9-16$ - šio darbo rezultatai. $T_{g}(\mathrm{~K}): 1,3,5,7,9,10,13,14-981,2,4,6,8,11,12,15,16$ - 1133; $T_{0}(\mathrm{~K}): 9,11,13,14-293 ; 10,12,15,16-333$

Laidumu šildomu lašeliu fazinių virsmu srautu kitimo būdingas kreives pateikus (7) išraiška, jos atspindimos universalia kreive (8 pav., $b)$. Išsamesnè analizė patvirtino, jog konvekcinès šilumos $\bar{q}_{c, k}^{+}$ir $\bar{q}_{c, k}^{-}$srautų kitimo kreives yra tapačios pateiktai $\bar{q}_{f, k}^{+}$kreivei.

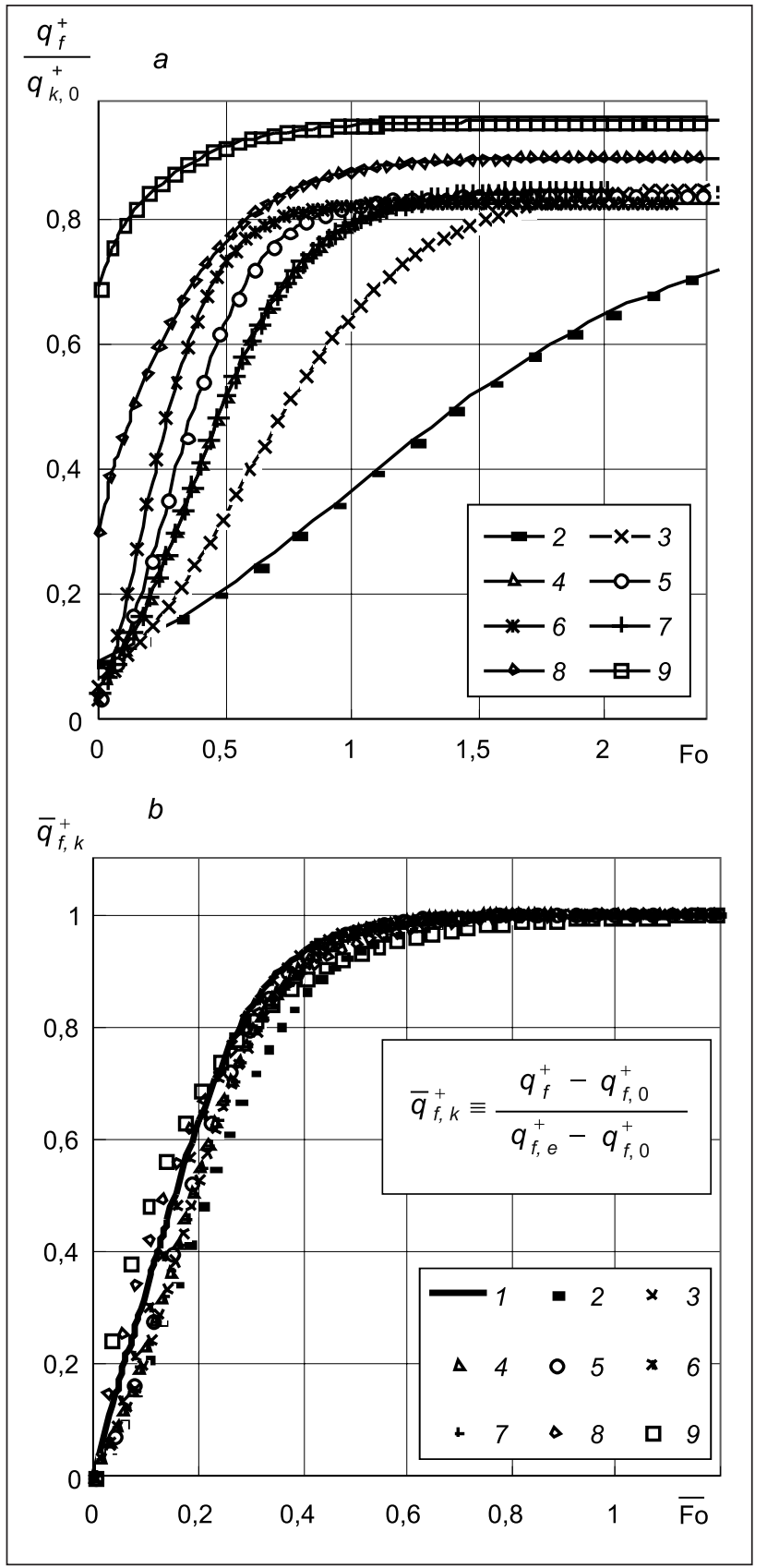

8 pav. Fazinių virsmy šilumos srauto kitimo būdingų kreivių priklausomumas nuo išpurškiamo vandens ir lašelio apsupties temperatūrų $(a)$ ir etaloninè fazinių virsmų šilumos srauto kitimo kreive (b). $T_{d} \mathrm{~K}: 2-473 ; 3-673 ; 4,7-11-873$; $5-1073 ; 6-1273 . T_{0} \mathrm{~K}: 2-7-278 ; 8-310 ; 9-325$

\section{APIBENDRINIMAS}

Lašelių fazinių virsmų analizei svarbūs (7) išraiška aprašomi $p_{\text {in }} \equiv m_{v}, p_{\text {in }} \equiv g_{v}$ bei $p_{\text {in }} \equiv R$ parametrai, o lašelių terminès būsenos kitimui $P \equiv T$ parametras, in indeksu išskiriant lašelio paviršiaus (in $\equiv R$ ), centro (in $\equiv C$ ) ir jo vidutinès masès (in $\equiv m$ ) būdingas temperatūras. Analizuojant šilumos srautus $P \equiv q$, in indeksu nurodomas pasirinktą šilumos srautą: in $\equiv c^{+}$, kai $P_{i n} \equiv q_{c}^{+}$; in $\equiv c^{-}$, kai $P_{i n} \equiv q_{c}^{-}$in $\equiv f^{+}$, kai $P_{i n} \equiv q_{f}^{+}$. 
Sudarius skirtingų parametrų $P_{i n, c} P_{\text {in, } k-r}$ bei $P_{i n, c-r}$ kitimo kreives ir jas palyginus su laidumu šildomų lašelių atitinkamų parametrų kitimo universaliomis kreivemis galima pateikti sisteminị sudètingesnių už laidumu lašelių šildymo atveju ịtakos jų terminei būsenai bei faziniams virsmams ịvertinimą. Tai yra tolesnių tyrimų tikslas.

\section{Žymejimai}

$a$ - temperatūros laidumo koeficientas $\mathrm{m}^{2} / \mathrm{s}$;

$B_{T}$ - Spoldingo šilumos pernešimo parametras;

$D$ - difuzijos koeficientas $\mathrm{m}^{2} / \mathrm{s}$;

Fo - Furje kriterijus;

$g$ - garavimo greitis $\mathrm{kg} / \mathrm{s}$;

$k_{e f}^{-}$- efektyvaus šilumos laidumo parametras;

$L$ - garavimo šiluma $\mathrm{J} / \mathrm{kg}$;

$m$ - garo srauto tankis $\mathrm{kg} /\left(\mathrm{m}^{2} \mathrm{~s}\right)$;

$\mathrm{Nu}$ - Nuselto kriterijus;

$n$ - nario indeksas begalinëje sumoje;

$p$ - slègis Pa;

$q$ - šilumos srauto tankis $\mathrm{W} / \mathrm{m}^{2}$;

$R$ - lašelio spindulys $\mathrm{m}$;

$R_{\mu}$ - dujų pastovioji J / (kmol K);

$r$ - lašelio koordinatè m;

$t$ - kontrolinis laikas s;

$T$ - temperatūra K;

$\eta=r / R$ - bemate koordinaté;

$\lambda$ - šilumos laidžio koeficientas $\mathrm{W} /(\mathrm{K} \mathrm{m})$;

$\mu$ - molekulinè masè $\mathrm{kg} / \mathrm{kmol}$;

$\rho-\operatorname{tankis~} \mathrm{kg} / \mathrm{m}^{3}$;

$\tau$ - laikas s.

\section{Indeksai apačioje:}

$c$ - konvekcija;

$C$ - lašelio centras;

$e$ - pusiausviras garavimas;

$f$ - faziniai virsmai;

$g$ - dujos;

$k$ - laidumas;

$m$ - masès vidutinis;

$R$ - lašelio paviršius;

$r$ - spinduliavimas;

$v$ - garas;

$v g$ - garo ir dujų mišinys;

$\Sigma$ - suminis;

0 - pradinè būsena;

$\infty$ - toli nuo lašelio.

\section{Indeksai viršuje:}

+ išorinè lašelio paviršiaus pusé;

- vidiné lašelio paviršiaus pusè.

\section{Literatūra}

1. Tseng C. C., Viskanta R. Enhancement of water droplet evaporation by radiation absorption. Fire Safety J. 2006. Vol. 41. P. 236-247.

2. Fuks N. A. Evaporation and Droplet Growth in Gaseous Media. London: Pergamum Press, 1959.

3. Williams A. Combustion of droplets of liquid fuels: a review. Combust. Flame. 1973. Vol. 21. P. 1-31.

4. Sirignano W. A. Fluid Dynamics and Transport of Droplets and sprays. Cambridge: Cambridge University Press, 1999.

5. Sazhin S. S. Advanced models of fuel droplet heating and evaporation. Progress in Energy and Combustion Science. 2006. Vol. 32. P. 162-214.

6. Miliauskas G., Šinkūnas S., Miliauskas G. Evaporation and condensing augmentation of water droplets in flue gas. Int. J. of Heat and Mass Transfer. 2010. Vol. 53. P. 1220-1230.

7. Sazhin S. S., Krutitskii P. A., Gusev I. G., Heikal M. R. Transient heating of an evaporating droplet. Int. J. of Heat and Mass Transfer. 2010. Vol. 53. P. 2826-2836.

8. Renksizbulut M., Nafziger R., Li X. A mass transfer correlation for droplet evaporation in high-temperature flows. Chem. Eng. Sci. 1991. Vol. 46. P. 2351-2358.

9. Abramzon B., Sirignano W. A. Droplet vaporization model for spray combustion calculations. Int. J. of Heat and Mass Transfer. 1989. Vol. 32. N 9. P. 1605-1618.

10. Miliauskas G., Sabanas V. Interaction of transfer processes during unsteady evaporation of water droplets. Int. J. of Heat and Mass Transfer. 2006. Vol. 49. P. 785-798.

11. Miliauskas G. Regularities of unsteady radiative-conductive heat transfer in evaporating semitransparent liquid droplets. Int. J. of Heat and Mass Transfer. 2001. Vol. 44. P. 785-798.

12. Dombrovsky L., Sazhin S. Absorption of thermal radiation in a semi-transparent. Int. J. of Heat and Fluid Flow. 2003. Vol. 24. P. 919-927.

13. Shcukin E. P., Krasovitov V. G., Jalamov J. I. Evaporation and condensative growth of large and moderately large droplets in gaseous media at any temperature differences. VINITI 3706-B091. 1991.

14. Miliauskas G., Sabanas V., Bankauskas R., Miliauskas G., Sankauskaite V. The peculiarities of sprayed liquid's thermal state change, as droplets are heated by conduction. Int. J. of Heat and Mass Transfer. 2008. Vol. 51. P. 4145-4160.

15. Miliauskas G., Šinkūnas S., Norvaišienè K. Influence of thermal radiation to the interaction of heat and mass transfer processes under evaporation of water droplets. ICCHMT'2011: 7th International Conference on Computational Heat and Mass Transfer. Turkey: Istanbul. 2011. P. 1-8.

16. Hale G. M., Querry M. R. Optical constants of water in the 200-nm to 200- $\mu \mathrm{m}$ wavelength region. Appl. Opt. 1973. Vol. 12. P. 555-562.

17. Kuzikovskij A. V. Dynamic of spherical particle in powerful optical field. Izv. VUZ Fizika. Vol. 5. P. 89-94.
Gauta 20110420

Priimta 20110804 
Gintautas Miliauskas, Kristina Norvaišienè

INFLUENCE OF THERMAL RADIATION ON THE ENERGETIC STATE AND EVAPORATION OF WATER DROPLETS

Summary

The modelling of water droplet evaporation was carried out for droplets under combined heating when the temperature of the external radiant source equalled the ambient temperature of droplets. The results of research are presented in the universal time scale expressed by the Fourier number. The influence of thermal radiation on the energetic state and evaporation of droplets is estimated by assessing the deviation of curves describing the variation of energy flow and evaporation parameters from the etalon curves. The abovementioned etalon curves considered as the curves representing the variation of the energy flows and evaporation parameters of conductively heated droplets as the time expressed by the Fourier number does not depend on the dispersity of droplets. The influence of the thermal radiation of evaporating droplets on the interaction of transfer processes is shown. Radiant influence on larger droplets is more significant and increases with the ambient temperature.

Key words: water droplets, evaporation and combined heating, interaction of transfer processes

\section{Гинтаутас Миляускас, Кристина Норвайшене \\ ВЛИЯНИЕ ТЕПЛОВОГО ИЗЛУЧЕНИЯ НА ЭНЕРГЕТИЧЕСКОЕ СОСТОЯНИЕ И ПРОЦЕСС ИСПАРЕНИЯ КАПЕЛЬ}

Резюме

Смоделировано испарение капель воды в случае сложного их нагрева при наличии источника внешнего излучения, температура которого соответствует температуре каплю окружающей среды. Результаты исследования представлены в универсальном масштабе критерия Фурье. Влияние теплового излучения на энергетическое состояние и испарение капли оценено по степени отклонения кривых изменения энергетических потоков и параметров испарения от эталонных кривых. Ими были приняты кривые изменения энергетических потоков и параметров испарения при кондуктивном нагреве капли, которые в масштабе критерия Фурье не зависят от дисперсности капель. Выявлено влияние теплового излучения на взаимодействие процессов переноса испаряющейся капли. Влияние теплового излучения более существено для крупных капель и возрастает с увеличением температуры среды.

Ключевые слова: капля воды, испарение и сложный нагрев, взаимодействие процессов переноса 